\title{
Preface to Special Issue on Critical Minerals Part II
}

\section{Mary M. Poulton ${ }^{1} \cdot$ Chee S. Theng ${ }^{2}$}

Published online: 7 January 2020

(C) Society for Mining, Metallurgy \& Exploration Inc. 2020

A journal's editors and reviewers can make or break the journal, and as our Mining, Metallurgy \& Exploration (MME) journal comes to the end of 2019 and embarks on 2020, our thoughts run to the cadre of more than 50 associate editors, led by Editors-in-Chief Ronel Kappes, Jürgen Brune, and Virginia McLemore, and over 400 reviewers without whom the success of MME would have been impossible.

MME has been an unequivocal success by a number of measures. In 2019, the journal published 110 papers in print with another 42 papers published online, more than double the target of 70 papers set for it over a year ago by the Society for Mining, Metallurgy \& Exploration's (SME) Board of Directors. At the time, the Board approved an update of the name of the flagship technical journal that the Society has been publishing since 1984, from Minerals \& Metallurgical Processing to Mining, Metallurgy \& Exploration, to better reflect the breadth and depth of the Society. Along with the name change, they approved a lateral move to publish the newly renamed journal in collaboration with Springer Nature, a decision that has proved to be mutually rewarding.

The authors of MME's papers now come from nearly 50 countries, ranging from Australia to Zambia, making the journal truly international, and they span the spheres of academia, government, and industry. In 2019, three special issues were organized: the Special Issue on Mineral and Metallurgical Processing in Honor of Emeritus Professor Douglas W. Fuerstenau, followed by the Special Issue on Emerging Technologies/Fourth Industrial Revolution in Mining, and the Special Issue on Critical Minerals. With 2020, we begin the year with seven overflow papers from the Special Issue on

Chee S. Theng

theng@smenet.org

Mary M. Poulton

mpoulton@email.arizona.edu

1 University of Arizona, Tucson, AZ, USA

2 Society for Mining, Metallurgy \& Exploration, Englewood, CO, USA
Critical Minerals and more than 20 additional regular papers. This will be followed later in the year by a Special Issue on Miner Safety and Health in the Fourth Industrial Revolution. Already lined up for 2021 are a Special Issue on Gangue Minerals and a Special Issue on Tailings.

Unseen but critical behind the publication of MME's papers are the tens of thousands of volunteer hours spent by editors and reviewers to review the over 500 papers submitted to the journal in 2019. They recommended revisions to improve the papers, reviewed the revisions, rejected those that failed to make the grade, and accepted those that would further the knowledge of the community. Like our authors, our editors and associate editors cover the globe. They represent more than 30 countries, and the one common thread running through them is a strong sense of duty and commitment to the mining and mineral fellowship.

To these selfless editors and reviewers, we extend a warm thank you! We will be sending individual messages of gratitude and appreciation to each of you, and in this issue, we wish you all a wonderful 2020.

Mary M. Poulton, Ph.D.

Executive Editor

Mining, Metallurgy \& Exploration (MME)

Chee S. Theng

Managing Technical Editor

Society for Mining, Metallurgy \& Exploration (SME)

Publisher's Note Springer Nature remains neutral with regard to jurisdictional claims in published maps and institutional affiliations. 